\title{
Effects of Torbangun Leaves(Coleus amboinicus Lour) Extract on Blood Glucose and Super Oxide Dismutase Activity in Hyperglycemic Rats
}

\author{
Meilla Dwi Andrestian" ${ }^{12^{*}}$, Muhammad Rizal Martua Damanik ${ }^{2,3}$, Faisal Anwar ${ }^{2}$, \\ Nancy Dewi Yuliana ${ }^{4}$ \\ ${ }^{1}$ Banjarmasin Health Polytechnic, Banjarbaru 70714, Indonesia \\ ${ }^{2}$ Department of Community Nutrition, Faculty of Human Ecology, IPB University, \\ Bogor 16680, Indonesia \\ ${ }^{3}$ SEAFAST Center, IPB University, Bogor 16680, \\ ${ }^{4}$ Department of Food Science, Faculty of Agricultural Engineering and Technology, IPB University, \\ Bogor 16680, Indonesia
}

\begin{abstract}
This research aimed to analyze the yield of torbangun extract, flavonoid content, and antioxidant activity of TE-S and its effect on the activity of SOD enzymes and blood glucose level in hyperglycemic rats as a DM animal model. The water content of simplicia was measured by the gravimetric method. The antioxidant activity of TE-S was determined using the DPPH method, while the total flavonoid was measured using spectrophotometry. The study was a completely randomized design using 25 Sprague Dawley rats. Rats were divided into four groups, namely NG (negative control, hyperglycemic rats), $\mathrm{N}$ (normal rats), H-IM (control of metformin drugs $62.5 \mathrm{mg} / \mathrm{kg}$ of BW), and H-IT (TE-S $620 \mathrm{mg} / \mathrm{kg}$ of BW). The treatment was carried out for 14 days. FBG levels were taken on day $0,4,7,11$, and 14 , measured using a glucometer, while blood serum SOD levels were measured using ELISA. The study showed the water content of torbangun simplicia was $7.99 \%$ and TE-S yield from simplicia was $4.69 \%$. TE-S contains total flavonoids of $3.91 \%$ and antioxidant activity $\left(\mathrm{IC}_{50}\right)$ of $306.28 \mathrm{ppm}$ with a standard of $1 \mathrm{ppm}$ vitamin C. TE-S treatment significantly decreased FBG $(\mathrm{p}=0.005, \alpha=0.01)$ and increased SOD levels in hyperglycemic rats. TE-S has the potential to increase blood serum SOD levels by contributing to the availability of antioxidants and decreasing blood glucose levels in hyperglycemic rats.
\end{abstract}

Keywords: flavonoid, hyperglycemia, sonication, superoxide dismutase, torbangun

\section{INTRODUCTION}

Diabetes Mellitus (DM), which is characterized by hyperglycemia, is associated with increased oxidative stress and vascular complications. Further, oxidative stress will cause changes in carbohydrate and lipid metabolism. This condition stimulates an increase in the formation of Reactive Oxygen Species (ROS) that can cause the $\beta$-pancreatic cell dysfunction, which in turn can reduce the antioxidant defense system (Retnaningsih et al. 2013). One of the antioxidant defense systems is the Superoxide Dismutase (SOD), which is the earliest detoxification enzyme and the most powerful antioxidant in the cell (Ighodaro \& Akinloye 2017). SOD is an essential enzyme capable of removing radical superoxide, so it can protect cells against toxic byproducts from aerobic metabolism (Mansuroglu et al. 2014).

The use of oral DM drugs accompanied by the use of natural ingredients is a common practice and about 1,050 anti-diabetes mellitus (anti-DM) plants have been studied (Subramoniam 2016). One of plants that have been commonly utilized as functional food and have been developed to help control DM is torbangun (Coleus amboini$\mathrm{cus}$ Lour.). Torbangun leaf has been consumed by Bataknese breastfeeding women in Indonesia in order to stimulate the milk production (Damanik et al. 2001, Damanik et al. 2006, Damanik 2009). In addition, the torbangun plant has been widely developed for other uses, among others as antibacterial and antifungal, controlling blood pressure and cholesterol, controlling pre-menstrual syndrome, and as DM therapy. Since 2016, torbangun leaves have been recognized as one of the original herbal medicine formularies in the Indonesian Minister of Health Regulation No. 6, Year 2016 (Kemenkumham 2016).

Several studies have examined the potential of the leaves of torbangun in DM treatment. Suryowati et al. (2015a) found that torbangun leaves extract can improve symptoms caused by

"Corresponding Author: tel: +62 8111174065, email: meilladwi74@gmail.com 
oxidative stress in DM rats. Furthermore, Suryowati (2015) found that torbangun leaves extract at a dose of $620 \mathrm{mg} / \mathrm{kg}$ of BW for 14 days had the potential to reduce blood glucose levels and free radicals, increase glucokinase enzymes, and protect the pancreatic $\beta$-cells in rats induced by Streptozotocin (STZ). Previously, Viswanathaswamy et al. (2011) reported that torbangun leaves extract could improve the function of pancreatic tissue and showed an insulin tropic effects (production, secretion, and insulin activity) in experimental animals.

It has been shown in previous study that the pancreatic $\beta$-cells in DM subjects had a very low SOD (Jung et al. 2017). Thus, through this mechanism, the flavonoids in torbangun leaves extract can act as an antioxidant that help the DM recovery process (Suryowati et al. 2015b). Suryowati et al. (2015b) used the maceration method to extract the torbangun leaf and it produced an extract containing $1.612 \%$ flavonoids. The conventional extraction methods from plant materials, especially methods such as maceration and Soxhlet extraction, are very time consuming and require relatively large amounts of solvents $(\mathrm{Xu}$ et al. 2015). Hemwimol et al. (2006) found that the use of sonication in the extraction process can improve extraction efficiency because it produces more metabolites with a shorter processing time and lower solvent consumption. Since the extraction process affects the metabolites produced, therefore, it is necessary to analyze the yield of extract, flavonoid content, and antioxidant potential of torbangun leaves extract obtained from sonication extraction method and its effect on the activity of SOD enzymes and blood glucose level in hyperglycemic rats.

\section{METHODS}

\section{Design, location, and time}

This study used a Completely Randomized Design (CRD). The research was held at the Bogor Crops and Medicines Research Institute for the manufacture of simplicia and extraction; Educational Animal Hospital, IPB University, Bogor for the maintenance of rats; and Laboratory of Physiology, Faculty of Medicine, Brawijaya University, Malang for analysis of SOD activities, from February 2017 to February 2018 . The study was conducted based on ethical treatment agreement No. 77-2017 from the Animal Ethics Commission, Institute for Research and Community Service, IPB University.

\section{Procedures}

Torbangun leaves were obtained from gardens in the Cibeureum, Bogor City (6 $0^{\circ} 7^{\prime} 31.47^{\prime \prime}$ S, $106^{\circ} 47^{\prime} 60.85^{\prime \prime} \mathrm{E}$ ), at an altitude of $298 \mathrm{~m}$ above sea level. Torbangun leaves were harvested at the age of 8 weeks, taken about $15 \mathrm{~cm}$ from the top of the plant (Andarwulan et al. 2014). Plant samples were identified by the Botanical Gardens Conservation Center, Indonesian Institute of Sciences, Bogor (No B-2096/IPH.3./KS/ VII/2017). The experimental animals used were 25 male Sprague-Dawley rats aged 8 weeks, with a minimum body weight of $140 \mathrm{~g}$ from PT. Indoanilab Bogor. The sample size was determined by the Federer's formula with $n$ as the number of sample and $t$ as the number of group:

$$
(\mathrm{n}-1) \times(\mathrm{t}-1) \geq 15
$$

Extraction. Torbangun leaves extraction followed the steps of Suryowati et al. (2005) with modification by the addition of a sonication step. Before extraction, the water content of torbangun simplicia was tested using the gravimetric method according to ISO 712:2009 (BSN 2015). Extraction was carried out by dissolving $25 \mathrm{~g}$ of torbangun leaves simplicia powder into $250 \mathrm{ml}$ ethyl alcohol $96 \%$ solvent followed by sonication with Powersonic sonicator 505 at $40 \mathrm{KHz}$ for 40 minutes at room temperature $\left(25^{\circ} \mathrm{C}\right)$. The extract was then filtered with Whatman filter paper (Annegowda et al. 2012). Sonication step was repeated twice with the addition of $100 \mathrm{ml}$ ethanol in each repetition. Solvent evaporation of the extract was carried out with a rotary evaporator at temperature of $60^{\circ} \mathrm{C}$ until semi solid liquid was obtained (Viswanathaswamy et al. 2011). The extract obtained was stored at $4^{\circ}-8^{\circ} \mathrm{C}$ (Uma et al. 2011). The percentage of extract was calculated based on the weight of the extract compared to the weight of the simplicia.

Flavonoid content. Measurement of flavonoid content was carried out by the colorimetric method (BPOM RI 2010). Two hundred $\mathrm{mg}$ of torbangun leaves extract was dissolved in $1 \mathrm{ml}$ of hexamethylentetraamine $\left(\mathrm{C}_{6} \mathrm{H}_{12} \mathrm{~N}_{4}\right)$ solution, 20 $\mathrm{ml}$ of acetone, and $2 \mathrm{ml}$ of $\mathrm{HCl}$, then hydrolyzed by refluxing for 30 minutes. The mixture was filtered using cotton and the filtrate was stored in a $100 \mathrm{ml}$ volumetric flask. The residue was refluxed again with $20 \mathrm{ml}$ of acetone for 30 minutes, filtered, and added to the previous volumetric flask. Acetone was added to the filtrate mixture up to a final volume of $100 \mathrm{ml}$. Approximately $20 \mathrm{ml}$ of 
the filtrate was put into a separating funnel and mixed with $20 \mathrm{ml}$ of water and was extracted three times, each time with the addition of $15 \mathrm{ml}$ of ethyl acetate. Ethyl acetate fractions were collected and added with ethyl acetate up to a final volume of $50 \mathrm{ml}$. A blank solution was made by mixing $10 \mathrm{ml}$ of the standard solution with glacial acetic acid solution up to $25 \mathrm{ml}$. The sample solution was made by mixing $10 \mathrm{ml}$ of the sample extract solution mixed with $1 \mathrm{ml}$ of $\mathrm{AlCl} 3$ solution and glacial acetic acid solution up to $25 \mathrm{ml}$. Samples, quercetin standards, and blanks were measured by a spectrophotometric wavelength at $425 \mathrm{~nm}$. Calculation of sample flavonoid levels (\% weight for weight) was done using the following formula,

$$
\left[\frac{C p(A s-A b s)}{(A p-A b p)}\right] \times 1.25 \times \frac{100}{\text { sample weight }}
$$

where $\mathrm{Cp}$ stands for comparative concentration, As stands for sample absorbance, Abs as sample blank absorbance, Ap as comparative absorbance, and Abp as absorbance of the blank comparison.

Antioxidant activity. Antioxidant activities were measured using the DPPH method (1-diphenyl-2-picryl hydrazyl) (Salazar-aranda et al. 2011). DPPH stock $(125 \mu \mathrm{M})$ was made by dissolving $2.5 \mathrm{mg}$ DPPH in ethanol p.a up to 50 $\mathrm{ml}$ in a volumetric flask coated with aluminum paper. A total of $10 \mathrm{mg}$ of sample and vitamin C were dissolved in $1 \mathrm{ml}$ of DMSO and vortexed until completely dissolved. A total of $100 \mu$ of sample and vitamin $C$ were added to a microplate. Sample was then added with $100 \mu$ l ethanol p.a. The blank well contained $100 \mu \mathrm{L}$ ethanol p.a with the addition of $100 \mu \mathrm{L} \mathrm{DPPH}$, while the negative control only contained $200 \mu \mathrm{L}$ ethanol p.a. The microplate was then incubated at room temperature under dark condition for 30 minutes, then measured using an ELISA reader at a wavelength of $517 \mathrm{~nm}$. Antioxidant activity was calculated by using the following formula:

Scavenging effect of $\operatorname{DPPH}(\%)=\left(\frac{(A 0-A 1)}{A 0}\right) 100$

Intervention. A total of 25 rats were kept in cages, separated individually, and fed with standard feeding. Seven rats were separated and assigned as the normal $(\mathrm{N})$ group, while the remaining rats were injected with Streptozotocin (STZ) with a single dose of $40 \mathrm{mg} / \mathrm{kg} \mathrm{BW}$ (Jung et al. 2011). Verification of a diabetic condition was characterized by Fasting Blood Glucose (FBG) levels above $126 \mathrm{mg} / \mathrm{dl}$ (Akbarzadeh et al. 2007). Rats that received STZ induction became hyperglycemic on the third day after injection. Rats that showed confirmed hyperglycemia were divided into 3 groups: NG (negative control, hyperglycemia rats, 6 rats), H-IM (control of metformin drugs $62.5 \mathrm{mg} / \mathrm{kg} \mathrm{BW}, 6$ rats), and H-IT (intervention with torbangun extract $620 \mathrm{mg} / \mathrm{kg}$ $\mathrm{BB}, 6$ rats). Torbangun leaves extract was mixed with $0.3 \% \mathrm{w} / \mathrm{v} \mathrm{NaCMC}$ solution, while metformin was dissolved with distilled water to facilitate administration (Suryowati 2015). Intervention with torbangun leaves extracts and control of metformin drugs were administered using a feeding tube $1 \mathrm{ml}$ at the same schedule every day for 14 days (Suryowati 2015).

Blood glucose level. Fasting blood glucose level data were taken on day $0,4,7,11$, and 14, measured using a glucometer. Blood was taken from the tip of the tail and dropped on a glucometer strip.

Necropsy. On $15^{\text {th }}$ day after the intervention, rats were anesthetized with a mixture of ketamine $(90 \mathrm{mg})$ and xylazine $(10 \mathrm{mg})$. Blood was taken from the heart and centrifuged at a speed of $3000 \mathrm{rpm}$ for 15 minutes to obtain the serum part.

SOD activity. SOD activity of rat blood serum was measured by the Enzyme-Linked Immunosorbent Assay (ELISA) method following the analysis kit manual of the Bioassay Technology Laboratory, China. A standard stock solution of $12 \mathrm{ng} / \mathrm{ml}$ was made by mixing $120 \mu \mathrm{l}$ of a standard solution (concentration $24 \mathrm{ng} / \mathrm{ml}$ ) into a $120 \mu \mathrm{l}$ standard diluent. Then a serial dilution was carried out to produce a solution with various concentrations. A total of $50 \mu \mathrm{l}$ of standard solutions was transferred into the standard wells, while 40 $\mu 1$ of sample solutions was transferred to the sample wells. Then, a total of $10 \mathrm{ml}$ of SOD antibody was added to each of the sample well. A total of $50 \mu \mathrm{l}$ of streptavidin-HRP was then added to both standard and sample well and the plate was incubated for 60 minutes at $37^{\circ} \mathrm{C}$. The plate was then washed five times by soaking wells with $0.35 \mathrm{ml}$ of wash buffer for 30 seconds -1 minute for each washing. A total of $50 \mu \mathrm{l}$ of reagent A and $50 \mu \mathrm{l}$ of reagent $B$ were added to each well. The plate was covered with a new sealer and incubated for 10 minutes at $37^{\circ} \mathrm{C}$ in dark conditions. Fifty $\mu 1$ of stop solution was added to each well until the blue color turned yellow. The Optical Density (OD) of each well was determined using an ELISA-reader at wavelength of $450 \mathrm{~nm}$. 


\section{Data analysis}

Data were processed using Microsoft Excel 2013 data processing software and Predictive Analytics SoftWare (PSAW) 18. Differences in the value of initial and final FBG levels in each group were tested using Paired t-test method, while differences in SOD activity between treatments were analyzed using ANOVA.

\section{RESULTS AND DISCUSSION}

\section{Profile of torbangun leaves extract}

The water content of torbangun leaves simplicia was $7.987 \%$. This value was lower than the result of a study conducted by Iwansyah et al. (2017), which was $10.33 \%$, but higher than the research result of Suryowati (2015), which was $7.7 \%$. However, the water content value obtained in this study still conformed with the simplicia requirements according to the quality requirements of traditional medicines from Indonesian Drug and Food Control Agency, which is $\leq 10 \%$ (BPOM RI 2014).

The extract yield from simplicia was $4.69 \%$ that presented in Table 1. This result was lower than the yield of maceration extraction method obtained by Suryowati (2015), which was 5.3\%. Hemwimol et al. (2006) stated that actually only a small amount of electrical energy was transmitted through the solvents in the sonicator pool system, with the remainder of the energy absorbed by the wall and water inside the sonicator pool, thereby leading to a yield of sonication extracts that is not always greater than that of conventional methods.

In contrast to the yield of extracts, the results showed that the total value of flavonoids in sonication extract was $3.914 \%$. This value was more than double the total flavonoids obtained by Suryowati (2015) using the conventional maceration method, which was equal to $1.62 \%$. The high flavonoid content of torbangun leaf extract with the sonication method is in line with Hemwimol et al. (2006), who reported that sonication extraction process can increase the extraction of organic compounds contained in plant tissue by damaging cell walls and increasing mass transfer of cell contents.

Previous studies have shown differences between the results of sonication extraction and conventional methods. Svetlana (2013) and Aboshora et al. (2014) reported that the extraction process with sonication was able to increase total flavonoids in plant extracts. Azwanida (2015) stated that the extraction process with the help of
Table 1. Profile of torbangun leaves extract

\begin{tabular}{llc}
\hline \multicolumn{1}{c}{ Parameter } & \multicolumn{1}{c}{ Method } & Result \\
\hline $\begin{array}{l}\text { Water content } \\
\text { of simplicia } \\
(\%)\end{array}$ & Gravimetric & $7.99 \pm 0.32$ \\
$\begin{array}{l}\text { Extract yield } \\
(\%)\end{array}$ & Sonication & 4.69 \\
$\begin{array}{l}\text { Total flavonoid } \\
(\%)\end{array}$ & Spectrophotometric & $3.91 \pm 0.00$ \\
$\begin{array}{l}\text { Antioxidant } \\
\text { activity }\left(\mathrm{IC}_{50}\right)\end{array}$ & DPPH & $306.28 \pm 0.00$ \\
$(\mathrm{ppm})$
\end{tabular}

sonicator produced mechanical effects of acoustic cavitation from ultrasound. This can increase surface contact between solvents and samples, as well as cell wall permeability. This process allows changes in the physical and chemical properties of the material, so that the plant cell walls are damaged, which then can facilitate the release of compounds and increase mass transportation of solvents into plant cells. Furthermore, Xu et al. (2015) stated that extraction using ultrasonic is a more effective and environmentally friendly method to extract natural antioxidants from plant material, compared to conventional methods, such as maceration and Soxhlet extraction.

The antioxidant activity of torbangun leaves extract in this study was $306.279 \mathrm{ppm} / 1 \mathrm{p}$ $\mathrm{pm}$ vitamin C. Referring to the research of Suryowati et al. (2015b), the extract produced by the maceration method showed the DPPH IC $\mathrm{I}_{50}$ antioxidant activity of $297.942 \mathrm{ppm}$. Another study reported that the DPPH $\mathrm{IC}_{50}$ ethanol extract of torbangun's leaves from maceration method was $207.57 \mathrm{ppm} / 1 \mathrm{ppm}$ vitamin C (Bhattacharjee \& Majumder 2013). The variation in antioxidant activity could be possibly caused by differences in the types of flavonoid contents due to differences in the growing process and extraction methods. Utami et al. (2015) stated that extraction methods can produce differences in antioxidant activity.

\section{Animal test}

Blood glucose level. DM pathogenesis is characterized by metabolic disorders leading to a decrease in peripheral tissue response to insulin (Kangralkar et al. 2010). Damage to peripheral tissue occurs due to an increase in free radicals in the body. Streptozotocin specifically damages the pancreatic $\beta$-cells, leading to failure in insulin production and the blood glucose levels increase, which are characterized by $\mathrm{FBG} \geq 126 \mathrm{mg} / \mathrm{dl}$ (Akbarzadeh et al. 2007). Animal tests indicated that of torbangun leaves that extracted using sonica- 
tion was able to lower the blood glucose levels in hyperglycemic rats. Table 2 shows that there is a significant difference in blood glucose levels between the intervention using torbangun leave extract ( $p=0.005, \alpha=0.01)$ and the positive control $(\mathrm{H}-\mathrm{IM})(\mathrm{p}=0.002, \alpha=0.01)$.

A significant decrease in glucose levels within the H-IT group showed the effectiveness of torbangun leaves extract obtained from sonication in decreasing blood glucose level in hyperglycemic rats. This result is in line with the research by Suryowati et al. (2015a). This result might be related to the antioxidants contained in torbangun leaves extract, which are able to capture free radicals caused by hyperglycemia. The de-crease in the levels of free radical would cause the insulin receptor to work properly, allowing glucose to be transported into the cell. This would then lead to the glycogenesis process to occur and the process of gluconeogenesis decreases inside the cell (Visnathasway et al. 2011). According to Trifunschi and Ardelean (2013), flavonoids are responsible for powerful antioxidant properties that help in the prevention and treatment of various diseases. Furthermore, Jung et al. (2011) stated that based on studies conducted regarding the role of antioxidants in DM recovery, the potential for anti-hyperglycemia in plant extracts is related to one type of flavonoids or synergistic effects of various flavonoids contained.

SOD activity. As an antioxidant that plays a role in the first detoxification and strongest anti-oxidant in the cell (Ighodaro \& Akinloye 2017). SOD is an endogenous antioxidant enzyme that acts as the first component of the defense system against Reactive Oxygen Species (ROS). The SODs remove $\mathrm{O}_{2}{ }^{*-}$ by catalyzing its dismutation, one $\mathrm{O}_{2}$ being reduced to $\mathrm{H}_{2} \mathrm{O}_{2}$ and another oxidized to $\mathrm{O}_{2}$. As a result, potentially hazardous super oxide anions will decrease (Gill dan Tuteja 2010).

STZ-induced rats in general experienced a decrease in SOD activity (Retnaningsih et al. 2013). STZ plays a role in increasing superoxide production in mitochondria, which then activates protein kinase- $\mathrm{C}$ and the formation of advanced glycosylation end products (AGEs) that can interfere with $\beta$-cell function (Poitout and Robertson 2014). Damage to pancreatic $\beta$-cells would then continue to cause metabolic disorders that are manifested by increased blood sugar levels.

SOD activity test is one of the parameters in determining the presence of antioxidant activity. The basic principle of measuring SOD activity is the reaction between xanthine and xanthine ox-
Table 2. Rats' blood glucose levels before and after the intervention

\begin{tabular}{lcc}
\hline $\begin{array}{c}\text { Treatment } \\
\text { group }\end{array}$ & $\begin{array}{c}\text { Initial FBG } \\
(\mathrm{mg} / \mathrm{dl})\end{array}$ & $\begin{array}{c}\text { Final FBG } \\
(\mathrm{mg} / \mathrm{dl})\end{array}$ \\
\hline $\mathrm{NG}$ & $153.00 \pm 3.56$ & $167.33 \pm 14.58$ \\
$\mathrm{~N}$ & $100.86 \pm 6.20$ & $91.29 \pm 8.24$ \\
$\mathrm{H}^{-I M}{ }^{*}$ & $147.83 \pm 6.89$ & $103.17 \pm 2.21$ \\
H-IT* $^{*}$ & $155.83 \pm 9.55$ & $105.17 \pm 5.04$
\end{tabular}

*ANOVA significant at $\mathrm{p}<0.01$; FBG: Fasting Blood Glucose; NG: negative control; N: normal; H-IM: metformin drug control; H-IT: torbangun leaf extract intervention

idase, which produce superoxide radicals. SOD catalyzes the process of superoxide radical dismutation to $\mathrm{H}_{2} \mathrm{O}_{2}$, which is more stable (Widowati et al. 2015).

Figure 1 shows the low SOD activity in the NG group that had oxidative stress because the body had to work hard to eliminate oxidants caused by STZ induction. Although it was not significantly different statistically, the results showed an increase in SOD activity in the H-IT rat group, compared to the NG group.

The administration of torbangun leaves extract showed a marked decrease in blood glucose levels, but a less significant increase in SOD activity. This occurs because a decrease in blood glucose levels does not necessarily involve the SOD enzymatic antioxidant activity. Apart from SOD activity, a decrease in blood glucose levels is also influenced by other enzymatic antioxidant activities, such as glutathione peroxidase (GPx) and catalase (CAT) (Ighodaro dan Akinloye 2017). Meanwhile, the study of Kristina et al. (2016) in DM patients and healthy people showed that there was no significant difference in the antioxidant activity of SOD of the two groups. This due to the intake of exogenous antioxidant sources. Thus, it can be stated that the presence of torbangun leaves extract contributes to the availability of antioxidants and therefore, helping to maintain the balance of oxidants and antioxidants in the body.

Torbangun leaves extract contains flavonoids, which possess antioxidant abilities that inhibit the formation of free radicals. According to Suryowati et al. (2015b), the flavonoids in torbangun leaf extract that act as antioxidants and are capable of reducing oxidative stress are quercetin. Meanwhile, according to Widowati et al. (2015), the mechanism of action of flavonoids is by suppressing the formation of ROS 


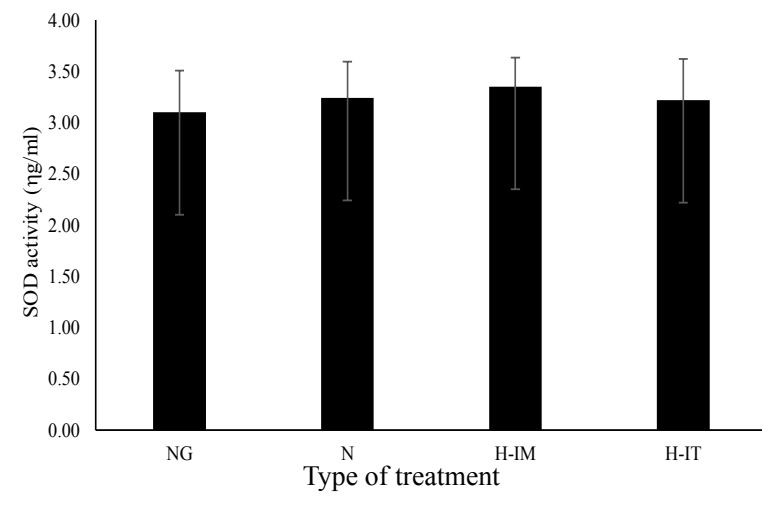

NG: negative control; N: normal; H-IM: metformin drug control; H-IT: torbangun leaf extract intervention

Figure 1. SOD activity at the end of intervention

by inhibition of enzymes and chelation of metals involved in production of radicals. Flavonoids work as primary antioxidants because of its scavenging capability against free radicals and ROS, such as superoxide anion and hydroxyl free radicals.

Flavonoids contained in torbangun leaves extract were able to provide protection against oxidative stress, which can be partially associated with a mechanism involving SOD activity. Jung et al. (2017) stated that this increase in SOD activity was able to prevent the death of pancreatic $\beta$-cells, thereby being able to recover hyperglycemia and insulin intolerance.

\section{CONCLUSION}

Torbangun leaves extract by sonication extraction method contains flavonoids, which have the potential to increase SOD levels by contributing to the availability of antioxidants and play a role in decreasing blood sugar levels in hyperglycemic rats. Therefore, due to the high level of antioxidant content in torbangun, there is a need for further study to confirm its benefits for DM prevention.

\section{ACKNOWLEDGEMENT}

The authors would like to thank the Center for Quality Improvement of Health Resources, Board for Development and Empowerment Human Resource of Health, Ministry of Health of the Republic of Indonesia, Banjarmasin Health Ministry Health Polytechnic, and the IPB University for access and technical support. The authors has no conflict of interest.

\section{REFERENCES}

Aboshora W, Lianfu Z, Dahir M, Qingran M, Qingrui S, Jing L, Al-haj NQM, Ammar AF. 2014. Effect of extraction method and solvent power on polyphenol and flavonoid levels in Hyphaene thebaica L Mart (Arecaceae) (Doum) fruit and its antioxidant and antibacterial activities. Trop J Pharm Res 13(12):2057-2063. doi: http://dx.doi.org/10. 4314/tjpr.v13i12.16.

Akbarzadeh A, Norouzian D, Mehrabi MR, Jamshidi Sh, Farhangi A, Verdi AA, Mofidian SMA, Rad BL. 2007. Induction of diabetes by streptozotocin in rats. Indian $\mathrm{J}$ Clin Biochem 22(2):60-64. doi: 10.1007/ BF02913315.

Andarwulan N, Yuliana ND, Hasna E, Aziz SA, Davis TD. 2014. Comparative analysis of three Torbangun clones (Plectranthus amboinicus (Lour.) Spreng) based on phenotypic characteristics and phenolic content. Am J Plant Sci 5(5):3673-3683. doi: 10.4236/ajps.2014.524383.

Annegowda HV, Bhat R, Min-tze L, Karim AA, Mansor SM. 2012. Influence of sonication treatments and extraction solvents on the phenolics and antioxidants in star fruits. J Food Sci Technol 49(4):510-514. doi: 10.1007/s13197-011-0435-8.

Azwanida, NN. 2015. A review on the extraction methods use in medicinal plants, principle, strength and limitation. Med Aromat Plants 4(3):3-8. doi: 10.4172/21670412.1000196.

[BPOM RI] Badan Pengawas Obat dan Makanan RI. 2010. Monografi Ekstrak Tumbuhan Obat Indonesia. Vol. 1. Direktorat Standarisasi Obat Tradisional, Kosmetik dan Produk Komplemen. Jakarta: Badan Pengawas Obat dan Makanan RI.

[BPOM RI] Badan Pengawas Obat dan Makanan RI. 2014. Peraturan Kepala BPOM RI Nomor 12 Tahun 2014 tentang Persyaratan Mutu Obat Tradisional. Jakarta: Badan Pengawas Obat dan Makanan RI.

Bhattacharjee P, Majumder P. 2013. Investigation of phytochemicals and anti-convulsant activity of the plant Coleus amboinicus (Lour.). Int J. Green Pharm 7(3):211215. doi: $10.4103 / 0973-8258.120223$.

[BSN] Badan Standardisasi Nasional. 2015. Current awareness service bulletin volume 3/No 5/2015. Jakarta: Badan Standardisasi Nasional. 
Damanik R, Damanik N, Daulay Z, Saragih S, Premier R, Wattanapenpaiboon N, Wahlqvist ML. 2001. Consumption of bangun-bangun leaves (Coleus amboinicus Lour) to increase breast milk production among Bataknese women in North Sumatera Island, Indonesia. Procceeding of the Nutritional Sosiety of Australia 10(4):S67.

Damanik R, Wahlqvist ML, Wattanapenpaiboon N. 2006. Lactagogue effects of torbangun, a Bataknese traditional cuisine. Asia Pac J Clin Nutr 15(2):267-274. doi: 10.2254/ 0964-7058.15.2.0253.

Damanik R. 2009. Torbangun (Coleus amboinicus Lour): A Bataknese traditional cuisine perceived as lactagogue by bataknese lactating women in Simalungun, North Sumatera, Indonesia. J Hum Lact 25(1):6472. doi: $10.1177 / 0890334408326086$.

Gill SS, Tuteja N. 2010. Reactive oxygen species and antioxidant machinery in abiotic stress tolerance in crop plants. Plant Physiol Biochem 48(12):909-930. doi: 10.101 6/j.plaphy. 2010.08.016.

Hemwimol S, Pavasant P, Shotipruk A. 2006. Ultrasound-assisted extraction of anthraquinones from roots of Morinda citrifolia. Ultrason Sonochem 13(6):543-548. doi: 10.1016/j.ultsonch.2005.09.009.

Ighodaro OM, Akinloye OA. 2017. First line defence antioxidants-superoxide dismutase (SOD), catalase (CAT) and glutathione peroxidase (GPX): Their fundamental role in the entire antioxidant defence grid. Alexandria Med J 54(4):287-293. doi: 10. 1016/j.ajme.2017.09.001.

Iwansyah AC, Damanik MRM, R, Kustiyah L. Hanafi M. 2017. Potensi fraksi etil asetat daun Torbangun (Coleus amboinicus L.) dalam meningkatkan produksi susu, bobot badan tikus, dan anak tikus. J Gizi Pangan 12(1):61-68. doi: 10.25182/jgp.2017.12.1. 61-68.

Jung H, Kim YY, Kim B, Nam H, Suh JG. 2017. Improving glycemic control in model mice with type 2 diabetes by increasing superoxide dismutasi (SOD) activity using silk fibroin hydrolysate (SFH). Biochem Biophys Res Commun 493:(1):115-119. http: //dx.doi.org/10.1016/j.bbrc.2017.09.066.

Jung JY, Lim Y, Moon MS, Kim, JY, Kwon O. 2011. Onion peel extracts ameliorate hyperglycemia and insulin resistance in high fat diet/streptozotocin-induced diabetic rats. Nutrition \& Metabolism 8(18):1-8. https://doi.org/10.1186/1743-7075-8-18.

Kangralkar VA, Patil SD, Bandivadekar RM. 2010. Oxidative stress and diabetes: A review. International Journal of Pharmaceutical Applications 1(1):38-45.

[Kemenkumham] Kementerian Hukum dan Hak Asasi Manusia RI. 2016. Peraturan Menteri Kesehatan Republik Indonesia No 6 Tahun 2016 Tentang Formularium Obat Herbal Asli Indonesia. Jakarta: Kementerian Hukum dan Hak Asasi Manusia RI.

Kristina H, Sartono N, Rusdi. 2016. Kadar peroksida lipid dan aktivitas superoksida dismutase serum darah pada penderita diabetes melitus tipe 2. Bioma 12(1):1-11. doi: 10.21009/Bioma.

Mansuroglu B, Derman S, Yaba A, Kizilbey K. 2014. Protective effect of chemically modified SOD on lipid peroxidation and antioxidant status in diabetic rats. Int $\mathrm{J}$ Biol Macromol 72:79-87. doi: 10.1016/j. ijbiomac.2014.07.039.

Poitout V, Robertson RP. 2008. Glucolipotoxicity: Fuel excess and $\beta$-cell dysfunction. Endocrine Review 29(3):351-366. doi: 10.1210/er.2007-0023.

Retnaningsih C, Darmono, Widianarko B, Muis SF. 2013. Peningkatan aktivitas antioksidan superoksida diamutase pada tikus hiperglikemi dengan asupan tempe koro benguk (Mucuna pruriens L). Agritech 33(2):154-161.

Salazar-aranda R, Perez-Lopez LA, Lopez-Arroyo J, Alanis-Garza BA, Torres NWD. 2011. Antimicrobial and antioxidant activities of plants from Northeast of Mexico. Evidence-Based Complementary and Alternative Medicine 2011. doi: 10.1093/ecam/nep127.

Subramoniam, A. 2016. Anti-Diabetes Mellitus Plants. Boca Raton: CRC Press.

Suryowati T. 2015. Efek ekstrak daun torbangun (Coleus amboinicus Lour) terhadap stres oksidatif tikus diabetes [Disertation]. Bogor: IPB University.

Suryowati T, Rimbawan, Damanik R, Bintang M, Handharyani E. 2015a. Antihyperlipidemic activity of torbangun extract ( $\mathrm{Co}-$ leus amboinicus Lour) on diabetic rats induced by streptozotocin. IOSR Journal of Pharmacy 5(5):50-54.

Suryowati T, Rimbawan, Damanik R, Bintang M, Handharyani E. 2015b. Identifikasi 
komponen kimia dan aktivitas antioksidan dalam tanaman torbangun (Coleus amboinicus Lour). J Gizi Pangan 10(3) :217-224.

Svetlana I, Ardelean, D. 2013. Flavonoid extraction from Ficus carica leaves using different techniques and solvents. Matica Srpska J Nat Sci 1(125):81-86. doi: 10.2298/ZMSPN1325081T.

Uma M, Jothinayaki S, Kumaravel S, Kalaiselvi P. 2011. Determination of bioactive components of Plectranthus amboinicus Lour by GC-MS analysis. New York Science Journal 4(8):66-69.

Utami RD, Yuliawati KM, Syafnir L. 2015. Pengaruh metode ekstraksi terhadap aktivitas antioksidan daun Sukun (Artocarpus altilis). Prosiding Farmasi Spesia Unisba. 2015:280-286.
Viswanathaswamy AHM, Koti BC, Gore A, Thippeswamy AHM, Kulkarni RV. 2011. Antihyperglycemic and antihyperlipidemic activity of Plectranthus amboinicus on normal and alloxan-induced diabetic rats. Indian J Pharms Sci 73(2):139-145. doi: 10.4103/0250-474X.91572.

Widowati W, Safitri R, Rumumpuk R, Siahaan M. 2015. Penapisan aktivitas superoksida dismutase pada berbagai tanaman. JKM 5(1):33-48.

Xu DP, Zhou Y, Zheng J, Li S, Li AN, Bin-Li H. 2015. Optimization of ultrasound-assisted extraction of natural antioxidants from the flower of Jatropha integerrima by response surface methodology. Molecules 21(18):1-12. doi: 10.3390/molecules 2101 0018 . 